\title{
Health care USA: Economic product or social good?
}

\author{
JOHN K IGLEHART
}

The Reagan administration's drive to reduce the scope and size of the federal government is placing America's social welfare programme in the eye of a gathering storm over the nation's priorities. Federal health programmes will be particularly vulnerable in this debate because government decision makers generally believe that budget reductions will punish medical care providers, not vulnerable beneficiaries.

Bolstered by a landslide re-election victory, President Reagan has moved quickly to advance his favoured philosophical formula: reduced federal spending, a continuation of the nation's military build up, and a determined bid to hold the line on tax increases. Reagan pursued this course during his first term, but because Congress refused to cut spending a requisite amount-while cutting taxes sharply and increasing the defence budget - the federal government now faces annual deficits of at least $\$ 200$ billion into the future.

The debate over the government's spending priorities will come in early 1985, after the president sends his fiscal 1986 budget to Congress around 1 February. Reagan made the task facing Congress more difficult by declaring -in the heat of the election campaign - that social security benefits would be cut only "over my dead body." These cash benefits to the disabled and elderly, defence outlays, to which Reagan is also substantially committed, and interest on the massive deficit represent two thirds of the federal budget. Thus the budget cuts that Reagan seeks must come largely from other forms of domestic spending.

The most likely political compromise, after all is said and done, seems to be a freeze on most forms of federal spending, including health care expenditures. The new Senate majority leader, Robert Dole, a moderate Republican from Kansas, favours such a freeze. But Dole also believes that some federal programmes must be eliminated if Congress is going to make substantial progress in reducing the government's massive deficit. Democrats who control the House of Representatives are likely to oppose a freeze because of the impact that it would have on poor and old citizens unless the defence budget is somehow made a part of this package.

This policy approach is likely to lead to even greater differences in the American and English models of medical care delivery. The philosophical difference represented by the two models can be boiled down to one question: is medical care an economic product or a social good? Britain's National Health Service clearly reflects a view of medical care as a social good. The health service has removed financial worry from the equation of individual illness. The Reagan administration, on the other hand, has declared since its first day that medical care should be regarded as an economic product. David Stockman, director of the president's office of management and budget, espoused this view as a Republican member of the House of Representatives even before his appointment to this high administration post in 1981 .

Addressing a conference in November 1980, Stockman outlined his belief that health care was an economic good that should be purchased by people who understood the financial consequences of their decisions. Stockman said that health care was somehow viewed differently, "as sort of a spiritual or social or collective good. As a consequence, it is treated, regulated, and managed by society in a unique way that departs from

Potomac, Maryland, USA

JOHN K IGI.EHAR'T

Correspondence to: 12008 River Road, Potomac, Maryland 20854, USA. the way in which markets normally handle other economic goods."

The result, Stockman concluded, is that "we have a total system that is out of control, a system that no one is satisfied with, not payers, not analysts, not consumers, and therefore, we are going to have to rethink that basic premise as well and ask whether somehow we can once again make health care an economic good ... so that we can bring into play those self regulatory, economising, efficiency producing mechanisms that we rely on in all other sectors."

\section{Making consumers and providers aware of the cost}

Given that philosophical bent, the Reagan administration generally promotes policies that underscore its conviction that medical care is an economic product. These policies will make consumers and providers alike more keenly aware of the cost of medical treatment. A freeze on medical care spending would seemingly hit most sharply the pocketbooks of doctors and the budgets of hospitals that treat a substantial number of publicly sponsored patients, but elderly beneficiaries could face a reduction in their access to care as well.

Another policy option that the administration is likely to put forward again is the taxing of employee fringe benefits, particularly employer paid health insurance premiums, which are now exempt from taxation. In early 1984 the administration proposed to tax as income to employees employer paid health insurance premiums exceeding $\$ 70$ a month for single workers and $\$ 175$ a month per family. Congressional committees held public hearings on the proposal but it was never voted on. The major congressional opponent of taxing fringe benefits is Senator Bob Packwood, an Oregon Republican who became chairman of the Senate finance committee, which oversees tax matters, when Dole was named Senate majority leader.

Packwood, interviewed on 2 December 1984 in the New York Times, cited anew his opposition to taxing health insurance premiums. "I much prefer using the tax code for incentives to the alternative, which is a government programme," Packwood explained. "The classic example is the difference between health insurance in this country and in Great Britain. Because of our employer paid health insurance programme, almost all of the people in this country who work never ask us about national health insurance. If we didn't have that employer provided programme, we'd probably have national health insurance, which would cost the government billions of dollars."

There are several policy reasons for taxing fringe benefits. Taxing such benefits would make the employee more cost conscious about the amount and type of insurance coverage that he selected and thus would help to moderate total health expenditures. To the extent that workers choose to continue purchasing comprehensive, first dollar coverage, this explicit decision would indicate their interest in securing this scope of protection and their willingness to pay for it, even though a portion of the premium would be taxed. Taxing benefits would also generate substantial new federal revenues, not an insignificant rationale in the current climate.

Medicare will also be subjected to new policies that reflect the administration's determination to make consumers recognise medical care as more economic product than social good. The beneficiaries of Medicare-some 30.5 million of the nation's elderly and disabled citizens-must already pay hospital deductibles and coinsurance and monthly premiums for services provided by doctors.

The amounts change annually, by law. Under Medicare 
part A (hospital insurance) the deductible patients pay for their hospital stay and this will change from $\$ 356$ to $\$ 400$, an increase of $12.4 \%$. The previous year the increase in the patient's deductible payment in Medicare was $17 \cdot 1 \%$. Each year, by law, the Medicare hospital deductible for the following year is computed to reflect the difference between average daily hospital costs for the previous year and the same costs during 1966, the year that Medicare began.

The rise in this deductible payment also increases the amount of coinsurance that beneficiaries must pay if they remain in the hospital for more than 60 days during 1985. From the 61 st to the 90th day of hospital stay the patient's share will increase from $\$ 89$ to $\$ 100$ a day. For stays beyond 90 days Medicare's patients' costs will go up from $\$ 178$ to $\$ 200$ a day. Under Medicare part B (doctors' services), the basic premium will also rise from $\$ 14.60$ to $\$ 15.50$ a month, effective from 1 January.

\section{Testing increased patient cost sharing}

Increased patient cost sharing-designed to make consumers more conscious of medical price tags-places the burden of a decision on whether to bear the cost of treatment on the patient. Many supporters of the Reagan government favour increasing the amount of patient cost sharing now required. Whether Congress would accept such a proposal in a deficit reduction package is an open question. A second approach which the administration is also following-consonant with its belief in the market-is the capitation model. That is, Medicare contracts with eligible organisations to provide beneficiaries all covered care for a single monthly payment.

The Department of Health and Human Services' Health Care Financing Administration, which manages Medicare, has conducted several demonstration projects to test the validity of this concept. Under these projects the financing administration contracted with health maintenance organisations to provide medical care to elderly citizens. Although the projects have not been formally evaluated, the financing administration is enthusiastic about the ability of health maintenance organisations to provide Medicare's benefits under a fixed fee established in advance.

Under the demonstration the financing administration established a fee of $95^{\circ}$ of what Medicare pays to fee for service providers in any given place. Thus, health maintenance organisations located in high cost areas such as Massachusetts and Florida had considerably more money to work with than those in low cost areas. One of the leading questions the financing administration is seeking answers to is which members of the elderly community enrolled in health maintenance organisations under these demonstrations. If they enrolled mostly healthy elderly people obviously they would fare better financially than if they signed up iller people who needed more medical care.

In any event, the concept of Medicare encouraging elderly citizens to enrol has attracted considerable support across the political spectrum. Congress has already approved legislation, contained in the Tax Equity and Fiscal Responsibility Act of 1982, which grants the Health Care Financing Administration the authority to contract on a general basis with health maintenance organisations and other health care organisations to enrol Medicare beneficiaries. Previously, it was authorised to experiment only with the concept.

The American Medical Association takes a dim view of this delivery approach. Stripped of the details, the association regards this legislation as a competitive threat to the interests of its fee for service members. Doctors who practise in health maintenance organisation settings, by and large, have not been joiners of the association. For several years the latter sought to derail the capitation approach, but its objections were ultimately rejected by Democratic and Republican legislators, who viewed care delivered by health maintenance organisations as a cost efficient alternative to fee for service medicine.
The American Medical Association will have its hands full on other fronts, though, in 1985. Congress has already imposed a 15 month freeze on Medicare's payments to doctors. There is a strong likelihood that Congress will extend that freeze as one element in the deficit reduction package. There is stronger sentiment than perhaps ever before among legislators that the government's methods for paying doctors must be reformed. The government's interest in reform was summed up in a background paper published in March 1984 by the United States Senate's special committee on aging entitled Medicare: Paying the Physician-History, Issues, and Options.

"The Medicare programme's physician payment policies need to be reconsidered in light of the federal budget deficit and a rapidly changing health system. In 1985, Medicare's supplementary medical insurance (physicians' services) will be the third largest federal domestic programme ( $\$ 25$ billion), exceeded only by social security and the Medicare hospital insurance programme. With a $16 \cdot 1 \%$ increase from 1984 to 1985, supplementary medical insurance will be the fastest growing of the major domestic programmes. Medicare's expenses for physicians' services are rising even more rapidly than private sector costs largely because it pays physicians on the basis of what they ask to be paid. The combination of provider determined rates and fee for service bills with a rapidly rising physician supply and new technology has accelerated spending for physicians' services. These payment policies-a compromise to gain physician acceptance when Medicare was enacted in 1965-have also distorted incentives for appropriate medical care and created unintended inequities among primary care physicians and specialists, inpatient and outpatient care, urban and rural areas."

Physician payment reform is only one of the items that will capture the attention of the American Medical Association in 1985. The association also will have to declare itself more forcefully on the question of medical care as an economic product or social good. The association has largely straddled the fence on that question, but it may well be forced to adopt a more clear cut position as the government makes its way through the thickets of its deficit reduction policy.

\section{THIRTY YEARS AGO}

It is estimated that an extra $£ 22 \mathrm{~m}$. will be spent on the National Health Service, England and Wales, during 1955-6, making a total of $£ 411 \mathrm{~m}$. Payments to hospitals will increase by nearly $£ 20 \mathrm{~m}$. to $£ 305 \mathrm{~m}$., an increase which includes an extra $£ 460,000$ in advances to hospital boards for capital account (total $£ 10 \mathrm{~m}$.) and an increase of $£ 19 \mathrm{~m}$. for advances for revenue account (total $£ 285 \mathrm{~m}$.). The estimates for teaching hospitals and regional hospital boards expenditure are $£ 40 \mathrm{~m}$. and $£ 254 \frac{1}{2} \mathrm{~m}$. respectively.

General medical, dental, pharmaceutical, and supplementary ophthalmic services are expected to cost $£ 133 \mathrm{~m}$., an increase of $£ 3 \frac{1}{2} \mathrm{~m}$. Out of this $£ 133 \mathrm{~m}$. it is estimated that payments to general practitioners will be nearly $£ 55 \mathrm{~m}$., an increase of $£ 2 \mathrm{~m}$., and the pharmaceutical service is expected to cost $£ 42 \mathrm{~m}$. (after deducting $£ 6 \mathrm{~m}$. for payments by patients), an increase of $£ 24,000$. The cost of the supplementary ophthalmic service will increase by $£ 648,000$ to $£ 8 \mathrm{~m}$. (after deducting $£ 5 \frac{1}{2} \mathrm{~m}$. for payments by patients). Compensation for the loss of right to sell medical practices is estimated at $£ 2 \frac{1}{2} \mathrm{~m}$., a decrease of $£ 56,000$.

The increase in expenditure on the National Health Service, Scotland, is estimated at $£ 2 \mathrm{~m}$., making $£ 52 \mathrm{~m}$. in all. The hospital estimates are increased by nearly $£ 2 \mathrm{~m}$., advances to boards on revenue account being increased by $£ 1 \frac{1}{2} \mathrm{~m}$. to a total of $£ 35 \mathrm{~m}$. Advances to boards on capital account remain the same as for 1954-5-that is, $£ 2 \mathrm{~m}$. Expenditure on general medical, dental, pharmaceutical, and supplementary ophthalmic services is estimated at $£ 16 \mathrm{~m}$. $(£ 407,000$ increase), of which $£ 7 \mathrm{~m}$. is for general medical services, $£ 5 \mathrm{~m}$. for pharmaceutical services, and $£ 760,000$ for supplementary ophthalmic services (increases of $£ 237,000, £ 30,000$, and $£ 40,000$ respectively). (British Medical fournal 1955;i:162.) 